\title{
Antena Mikrostrip Biosensor untuk Deteksi Virus pada Darah
}

\author{
YUSNITA RAHAYU, MEILITA KURNIATI, INESTI LAILATUL QODRIYAH
}

Fakultas Teknik, Jurusan Teknik Elektro, Universitas Riau, Indonesia Email: yusnita.rahayu@lecturer.unri.ac.id

Received 15 Februari 2021 | Revised 15 Maret 2021 | Accepted 2 April 2021

\begin{abstract}
ABSTRAK
Kemajuan teknologi gelombang mikro memainkan peran penting dalam berbagai aplikasi diagnosa dan deteksi penyakit. Penelitian ini mengusulkan dua model antena untuk mendeteksi virus menggunakan Antena Mikrostrip Biosensor yang beroperasi pada ISM band (2,4-2,5 GHz). Antena yang diusulkan disimulasikan pada Software CST dengan material substrat Roger 3010. Hasil simulasi yang diperoleh antena pertama beroperasi pada 2,46 GHz, return loss $-19,76 \mathrm{~dB}$, bandwidth 401,2 MHz. Antena kedua pada 2,45 GHz, return loss -22,51 dB, bandwidth 227,4 MHz. Hasil simulasi pengujian menggunakan phantom darah menunjukkan pergeseran frekuensi semakin rendah dengan antena pertama 2,38 $\mathrm{GHz}$ dan antena kedua 2,43 GHz. Pengukuran antena pertama beroperasi pada $2,5 \mathrm{GHz}$ dengan return loss $-21,55 \mathrm{~dB}$ dan antena kedua beroperasi pada 2,47 $\mathrm{GHz}$ dengan return loss $-28 \mathrm{~dB}$. Pengukuran antena menggunakan VNA menunjukkan pergeseran frekuensi semakin meningkat diikuti return loss semakin rendah dibandingkan dengan hasil simulasi.
\end{abstract}

Kata kunci: antena deteksi virus, ISM, proximity coupled, mikrostrip, phantom.

\begin{abstract}
Advances in microwave technology play an important role in a wide variety of disease diagnostic and detection applications. This study proposes two antenna models for virus detection using a Microstrip Biosensor antenna that operates on the ISM band (2.4-2.5 GHz). The proposed antenna is simulated in CST software with Roger 3010 substrate material. The simulation results obtained by the first antenna operate at $2.46 \mathrm{GHz}$, return loss of $-19.76 \mathrm{~dB}$, a bandwidth of 401.2 $\mathrm{MHz}$. The second antenna at $2.45 \mathrm{GHz}$, return loss of $-22.51 \mathrm{~dB}$, a bandwidth of $227.4 \mathrm{MHz}$. The test simulation results using blood phantom show that the frequency shift is getting lower with the first antenna at $2.38 \mathrm{GHz}$ and the second antenna at $2.43 \mathrm{GHz}$. The first antenna measurement operates at $2.5 \mathrm{GHz}$ with a return loss of $-21.55 \mathrm{~dB}$ and the second antenna operates at $2.47 \mathrm{GHz}$ with a return loss of $-28 d B$. Antenna measurement using VNA shows that the frequency shift is increasing followed by lower return loss compared to the simulation results.
\end{abstract}

Keywords: antena for virus detection, ISM, proximity coupled, microstrip, phantom. 


\section{PENDAHULUAN}

Infeksi virus yang terjadi secara terus menerus telah menjadi ancaman serius terutama bagi kesehatan masyarakat global (Luo \& Gao, 2020). Beberapa infeksi virus dapat berlangsung dalam waktu kurang dari satu minggu bahkan dalam jangka waktu panjang (Cabigas, 2020). Sejak tahun 1997 hingga saat ini berbagai variasi virus terus bermunculan hingga menjadi wabah. Wabah yang disebabkan oleh infeksi virus memberikan dampak yang signifikan dalam berbagai aspek kehidupan manusia mulai dari pendidikan, sosial hingga perekonomian (Abidah, dkk, 2020)(Development Bank, 2020)(Pawar, 2020). Tercatat pada 2003, persentase kematian yang disebabkan oleh infeksi virus sebanyak 9,6\%, dilanjutkan tahun 2012 persentase kematian lebih dari 30\% (Luo \& Gao, 2020). Dilanjutkan semenjak akhir tahun 2019 terjadi infeksi penyebaran virus corona dan dalam waktu tiga bulan menjadi pandemi global (Hariyani, dkk, 2020). Berdasarkan laman https://covid19.go.id/ yang diakses pada tanggal 4 Januari 2020, data sebaran virus corona secara global terkonfirmasi sebanyak 222 negara dengan lebih dari 83 juta orang di dunia terinfeksi dan lebih dari 1,8 juta angka kematian di seluruh dunia. Hingga saat ini dunia masih diselimuti oleh wabah dan mengakibatkan berbagai sektor mengalami kerugian. Hal ini memperlihatkan kasus infeksi virus merupakan ancaman serius bagi negara-negara di seluruh dunia yang perlu menjadi perhatian dan sangat penting untuk diselesaikan.

Berbagai upaya telah dilakukan untuk menekan laju penyebaran infeksi virus yang relatif cepat. Upaya dalam menghapus penyebaran ini sangat sulit bahkan tidak memungkinkan, namun laju penyebaran infeksi virus dapat diminimalisir, setidaknya mengimbangi dengan kemampun perawatan di dunia medis. Dengan demikian, resiko yang ditimbulkan dapat dihindari. Strategi yang telah diusulkan saat ini adalah dengan melalui uji polymerase chain reaction (PCR) dan swab tenggorokan (Hariyani, dkk, 2020). Meskipun demikian, strategi ini belum cukup efektif karena memerlukan waktu dan biaya yang relatif mahal. Proses diagnosa atau screening awal tidak dapat diterapkan dalam strategi tersebut. Tindakan noninvansive sebagai strategi lain yang dapat dipertimbangkan adalah dengan memanfaatkan kemajuan teknologi gelombang mikro yang mulai digunakan dalam berbagai aplikasi rekayasa biomedis di berbagai aplikasi sperti deteksi virus pada darah (Goudos, 2017).

Kemajuan teknologi gelombang mikro meningkatkan dalam mendiagnosa dan pengobatan terapeutik di berbagai aplikasi (Elsheikh, dkk, 2013). Metode alternatif yang diusulkan antara lain menggunakan teknologi gelombang mikro berupa antena mikrostrip untuk mendeteksi virus. Penelitian terkait aplikasi antena untuk deteksi virus telah dilakukan oleh beberapa peneliti. Penelitian oleh Elsheikh., dkk mengevaluasi virus dengan memanfaatkan teknologi gelombang mikro yakni antena mikrostrip. Antena yang diusulkan peneliti beroperasi pada dual band, pertama pada Industrial Science Medical (ISM) pada frekuensi 2.45 GHz dan pada Wireless Local Area Network (WLAN) pada frekuensi $5.2 \mathrm{GHz}$. Metode yang digunakan adalah dengan memperhatikan perubahan sifat kelistrikan darah seperti dielektrik, konduktivitas dan resistivitas di dalam antigen atau antibody. Penelitian ini memberi kesimpulan bahwa sensitivitas instrument tergantung wilayah uji dan frekuensi operasi (Elsheikh, dkk, 2013). Studi lanjutannya oleh Elsheikh., dkk mengidentifikasi serum darah yang terinfeksi virus entero yang akan beroperasi pada jalur Bluetooth di frekuensi $2.4 \mathrm{GHz}$ dengan menggunakan sensor mikroimun (Elsheikh, dkk, 2013). Penelitian lain oleh Dolai\&Tabib-Azar menggunakan sinyal Terahertz untuk mendeteksi virus Zika pada frekuensi kerja 0,75 THz - 1,1 THz (Dolai \& Tabib-azar, 2020). Penelitian oleh Keshavarz\&Vafapour mengemukakan deteksi tiga subtipe virus Avian Influenza (AI) H1N1, H5N2 dan H9N2 dengan menggunakan metamaterial biosensing Terahert (THz). Peneliti ini mendapati pergeseran resonansi frekuensi dari dari THZ metamaterial setelah virus 
diendapkan pada permukaan desain antena yang diusulkan. Penelitian ini menggunakan tiga subtipe virus tersebut dengan perbedaan konsentrasi protein dan nilai RI yang berbeda. Frekuensi utamanya $1,7164 \mathrm{THz}$, Virus $\mathrm{H} 1 \mathrm{~N} 1$ menggunakan frekuensi $1,668 \mathrm{THz}$, virus H5N2 menggunakan Frekuensi $1,665 \mathrm{THz}$ dan virus H9N2 menggunakan Frekuensi $1,641 \mathrm{THz}$ (Keshavarz \& Vafapour, 2019). Penelitan oleh Park dan lainnya mendemonstrasikan antena untuk deteksi virus dengan menggunakan resonator cincin terpisah (split-ring) Terahertz dengan berbagai kapasitas celah. Peneliti ini mendapati pergeseran frekuensi resonanasi metamaterial $\mathrm{THz}$ setelah virus mengendap di permukaan antena dengan kepadatan rendah. Pengukuran pada penelitian ini menggunakan konstanta dielektrik sebagai objek penelitian. Pergeseran frekuensi semakin meningkat dengan konstanta dielektrik yang relatif besar (Park, dkk, 2017). Penelitian oleh Cheng dan lainnya juga mengoperasikan antena pada THz. Penelitiannya menggunakan cross planar Jerussalam metamaterial absorber untuk deteksi virus yang didasarkan pada poof Surface Plasmon Polaritons (SSPPs) (Cheng, dkk, 2018). Penelitan oleh Zang dan lainnya mendeteksi virus Ebola dengan mendeteksi antigen dan antibodinya. Penelitian ini menggunakan sensor pengujian plasmonik 3D nano antena yang dikembangkan sebagai immunoassay on-chip. Biosensor yang digunakan berbasis nanoantena (Zang, dkk, 2019).

Pada penelitian ini dirancang antena mikrostrip biosensor untuk mendeteksi virus melalui darah manusia. Antena yang diusulkan akan beroperasi pada single band pada Industrial Scientific Medicine (ISM) frekuensi kerja 2,45 GHz (2,4-2,5 GHz) (Kiourti \& Nikita, 2012). Frekuensi kerja 2,45 untuk deteksi virus didasarkan pada kegunaan frekuensi ISM yang memang dialokasikan untuk kebutuhan dalam bidang kesehatan seperti pada aplikasi antena mikrostrip untuk biomedis, hal ini juga dikuatkan dengan referensi terkait (Elsheikh, dkk, 2013) pendeteksian virus yang menunjukkan frekuensi tersebut untuk melihat perubahan konstanta dielektrik sesuai dengan kebutuhan penelitian. Penelitian ini memaparkan dua model antena. Desain antena yang diusulkan dibuat dengan menggunakan software CST Studio Suite. Antena yang diusulkan pada penelitian ini menggunakan teknik pencatu proximity coupled feed. Teknik pencatuan yang penulis usulkan ditujukan agar dapat meningkatkan bandwidth dan meminimalisir radiasi tambahan. Penelitian ini menggunakan material substrat Roger 3010 dengan ketebalan 1,28 mm. Penelitian ini mememaparkan metode yang belum ada sebelumnya berupa pengujian dengan simulasi phantom darah. Pada penelitian ini penulis memaparkan antena yang dapat mendeteksi keberadaan virus secara umum melalui simulasi dengan menggunakan phantom serum darah.

\section{METODOLOGI}

\subsection{Spesifikasi Antena}

Pada penelitian ini, peneliti mengusulkan dua model antena dengan dimensi yang berbeda. Penulis mengusulkan dua antena yang berbeda dengan tujuan untuk membandingkan sensitivitas dari kedua antena dengan karakteristik yang berbeda. Tahapan perancangan pertama kali adalah menentukan karakteristik antena yang diharapkan sebagai berikut :

1. Frekuensi kerja : $2.4 \mathrm{GHz}(2.4 \mathrm{GHz}-2.5 \mathrm{GHz})$

2. Impedansi Masukan $: 50 \Omega$ Koaksial konektor SMA

3. Return loss : $\leq-10 \mathrm{~dB}$

4. Gain

$$
\text { : Optimum pada single patch }
$$

Dalam rancang bangun antena mikrostrip yang diusulkan, peneliti menggunakan perangkat keras (hardware) dan (software). Adapun perangkat keras yang digunakan adalah Pocket Vector Network Analyzer (VNA) untuk pengujian kinerja. Perangkat lunak yang digunakan 
adalah CST Software dalam hal perancangan desain antena dan melakukan simulasi untuk mengetahui karakterisitk atau kinerja antena mikrostrip.

\subsection{Diagram Alir}

Diagram alir dibuat dengan tujuan mempermudah dalam perancangan antena mikrostrip yang diusulkan dengan mengikuti langkah-langkah yang tersusun secara sistematis. Gambar 1 merupakan tampilan diagram alir yang digunakan dalam penelitian ini :

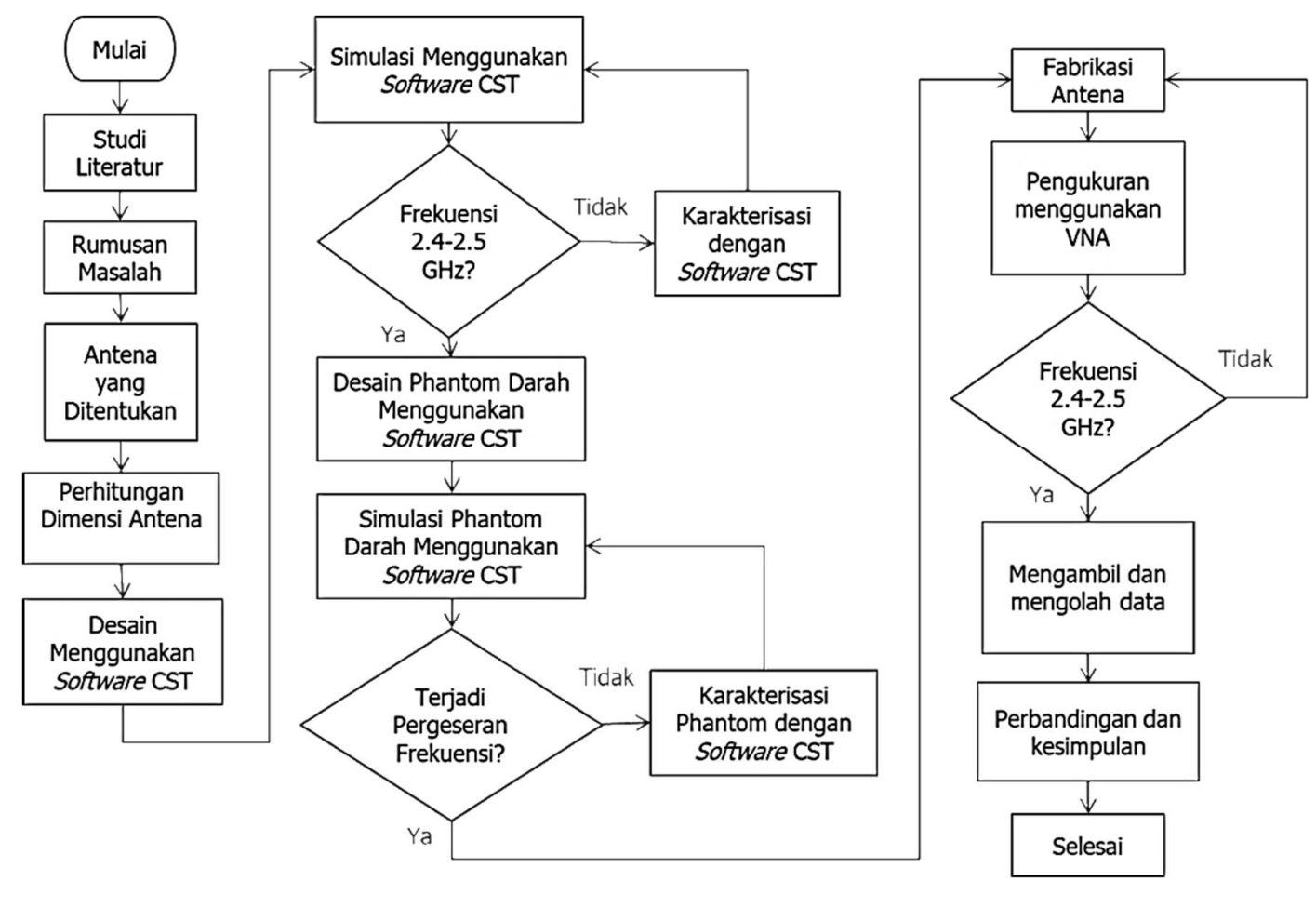

Gambar 1. Diagram Alir Rancang Bangun Antena

\subsection{Perancangan Antena}

Pada penelitian ini digunakan material substrat Roger 3010 dengan spesfikasi yang ditunjukkan pada Tabel 1 :

Tabel 1. Spesifikasi Substrat yang Digunakan

\begin{tabular}{|l|l|}
\hline Jenis Substrat & Roger 3010 \\
\hline Konstanta Dielektrik Relatif $(\varepsilon r)$ & 11,20 \\
\hline Dielektrik Loss Tangent $(\tan \delta)$ & 0,0022 \\
\hline Ketebalan Substrat $(h)$ & $1,28 \mathrm{~mm}$ \\
\hline
\end{tabular}

Setelah menentukan jenis substrat yang digunakan, selanjutnya adalah melakukan pengukuran dimensi antena secara teoritis (Balanis, 2012).

Perhitungan dimensi substrat antena dihitung dengan menggunakan Persamaan (1) :

$$
W=\frac{c}{2 f_{0} \sqrt{\frac{\varepsilon_{r}+1}{2}}}
$$


Dimana :

$W$ : Lebar konduktor (mm)

$\varepsilon_{r}$ : Konstanta Dielektrik Relatif $(\mathrm{V} / \mathrm{m})$

c : Kecepatan Cahaya Ruang Bebas $\left(3 \times 10^{8} \mathrm{~m} / \mathrm{s}\right)$

$f_{0}$ : Frekuensi kerja antena $(\mathrm{Hz})$

Perhitungan dimensi ground antena dihitung dengan menggunakan Persamaan (2) :

$$
A g=6 t+a
$$

Dimana :

$t$ : Ketebalan substrat

$a$ : Panjang saluran pencatu ditambah diameter dimensi patch

Resonansi frekuensi patch lingkaran antena dihitung dengan menggunakan Persamaan (3) :

$$
f_{\text {res }}=\frac{1.8412 c}{2 \pi a_{e} \sqrt{\varepsilon_{r}}}
$$

Dimensi feedline antena dihitung dengan menggunakan Persamaan (4) :

$$
L f=\lambda g
$$

Lebar mikrostrip line $(W f)$ antena dihitung dengan menggunakan Persamaan (5) :

$$
W f=2 \times h \pi \times[B-1-\ln (2 B-1) \times \varepsilon r-12 \varepsilon r \times[\ln (B-1)+0,39-0,61 \varepsilon r
$$

\subsection{Model Antena}

Setelah peneliti melakukan perhitungan dimensi antena secara teoritis, langkah selanjutnya peneliti mendesain antena dengan menggunakan software CST. Pada Gambar 2 - 6 merupakan tampilan desain kedua antena yang peneliti usulkan :

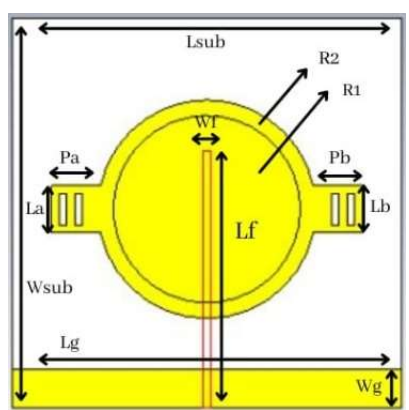

(a)

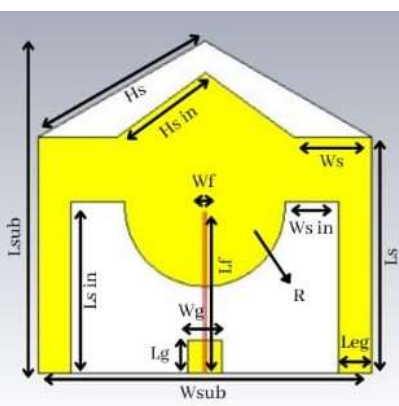

(b)

\section{Gambar 2. Tampak Depan (a) Antena Pertama dan (b) Antena Kedua}




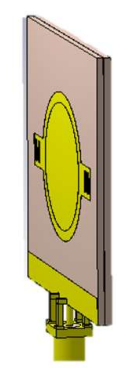

(a)

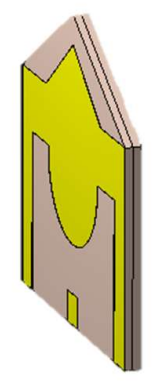

(b)

Gambar 3. Tampak Samping (a) Antena Pertama dan (b) Antena Kedua

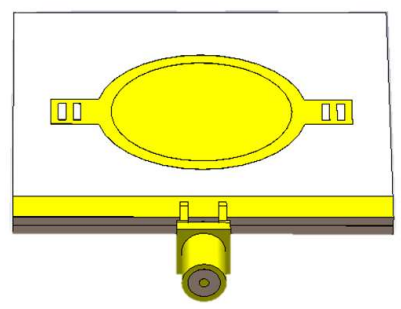

(a)

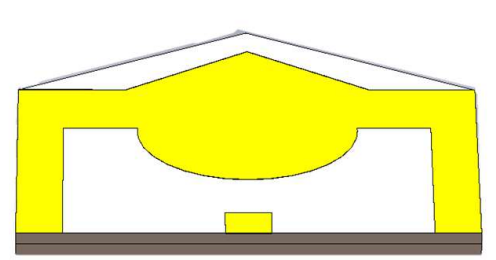

(b)

Gambar 4. Tampak Bawah (a) Antena Pertama dan (b) Antena Kedua

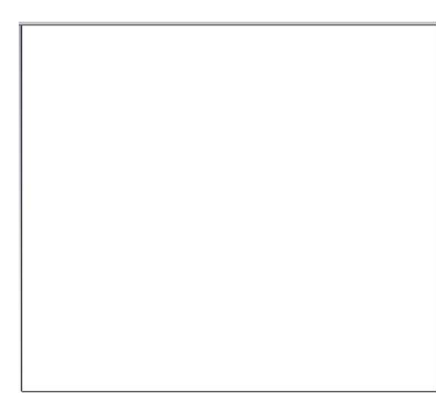

(a)

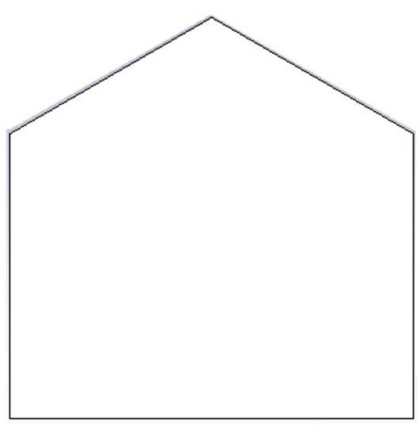

(b)

Gambar 5. Tampak Belakang (a) Antena Pertama dan (b) Antena Kedua

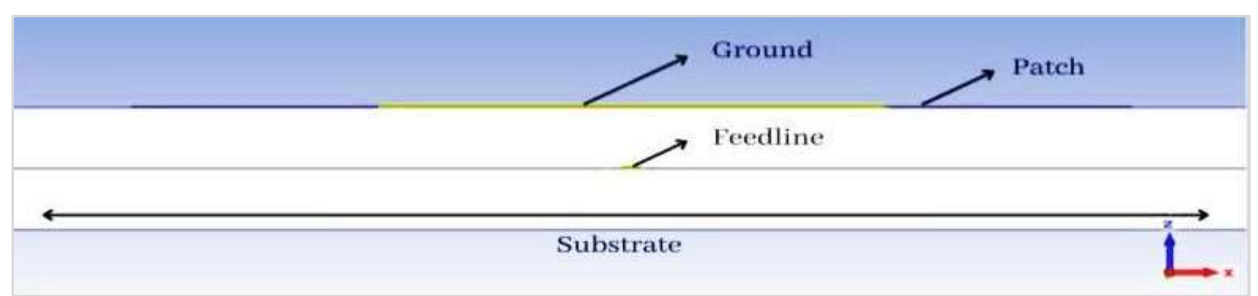

Gambar 6. Struktur Antena yang Diusulkan 
Gambar 2 sampai Gambar 4 menunjukkan desain geometris kedua antena dilihat dari sisi tampak depan, samping dan bawah. Sementara Gambar 5 sampai Gambar 6 menunjukkan sisi belakang dan struktur antena menggunakan teknik pencatuan proximity coupled feed. Pengujian antena menggunakan phantom darah ditunjukkan pada Gambar 7 sampai Gambar 8.

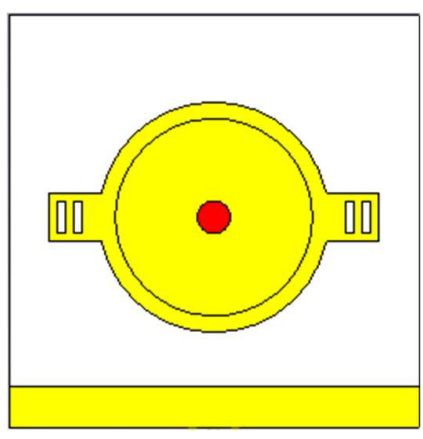

(a)

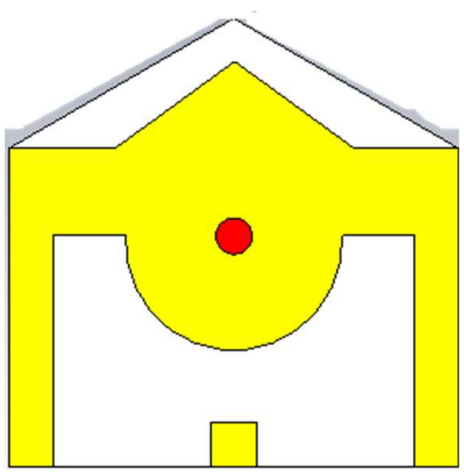

(b)

\section{Gambar 7. Tampak Depan (a) Antena Pertama dan (b) Antena Kedua dengan Phantom Darah}

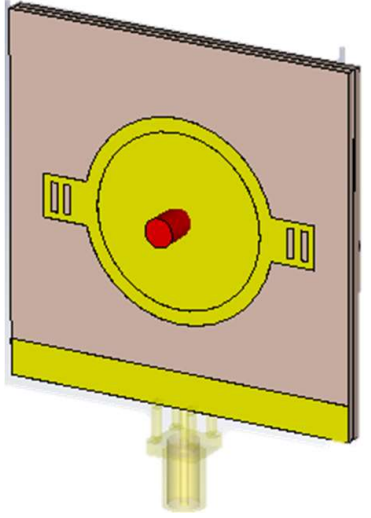

(a)

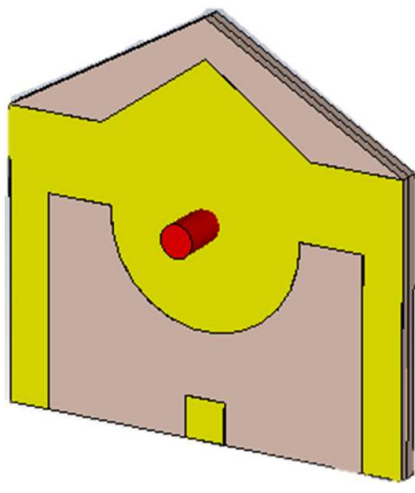

(b)

Gambar 8. Tampak Samping (a) Antena Pertama dan (b) Antena Kedua dengan Phantom Darah

\section{HASIL DAN PEMBAHASAN}

Antena yang diusulkan menggunakan teknik pencatu proximity coupled feed (Tong \& Huang, 2008), sehingga terdiri dari dua substrat dengan feedline yang terhimpit diantara kedua substrat tersebut. Dengan demikian, analisa hasil simulasi kinerja antena meliputi frekuensi, return loss $(\mathrm{dB})$, VSWR, Directivity $(\mathrm{dBi})$, Gain $(\mathrm{dBm})$, Bandwidth $(\mathrm{MHz})$ dan Impedansi Antena (Ohm). Tabel dimensi antena setelah dikarakterisasi ditunjukkan pada Tabel 2, dan hasil fabrikasi kedua antena menggunakan substrate Roger 3010 ditampilkan pada Gambar 9 dan Gambar 10. 
Tabel 2. Dimensi Antena

\begin{tabular}{|c|c|c|c|}
\hline \multicolumn{2}{|c|}{ Antena Pertama } & \multicolumn{2}{c|}{ Antena Kedua } \\
\hline Dimensi Antena & Parameter $(\mathrm{mm})$ & Dimensi Antena & Parameter $(\mathrm{mm})$ \\
\hline Lsub & 50 & Lsub & 50 \\
\hline Wsub & 50 & Wsub & 50 \\
\hline Hsub & 1,28 & Wg & 5 \\
\hline Wf & 1 & Wf & 0,3 \\
\hline Lf & 33 & R & 12 \\
\hline Wg & 5 & Rin & 10,5 \\
\hline Lg & 50 & Lg & 5 \\
\hline H & 0,036 & Lf & 24 \\
\hline R1 & 12 & Ls & 35,28 \\
\hline R2 & 14 & Ls in & 25,68 \\
\hline Pa & $-4,25$ & Hs & 16,45 \\
\hline $\mathrm{Pb}$ & 4,25 & Hs in & 28,9 \\
\hline La & 1 & Ws & 11,6 \\
\hline Lb & 1 & Ws in & 8 \\
\hline- & - & Ws Leg & 5 \\
\hline
\end{tabular}

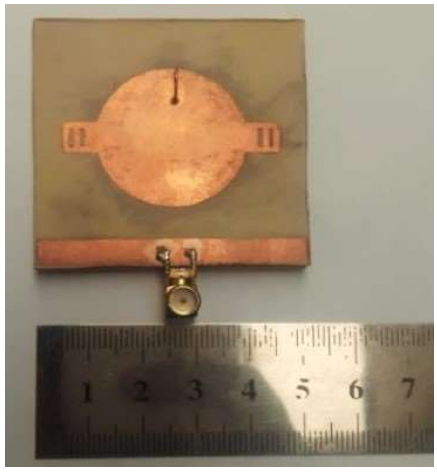

(a)

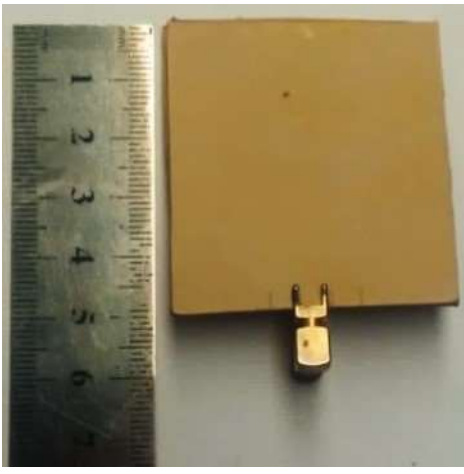

(b)

Gambar 9. Fabrikasi Antena Mikrostrip Pertama Tampak (a) Depan dan (b) Belakang

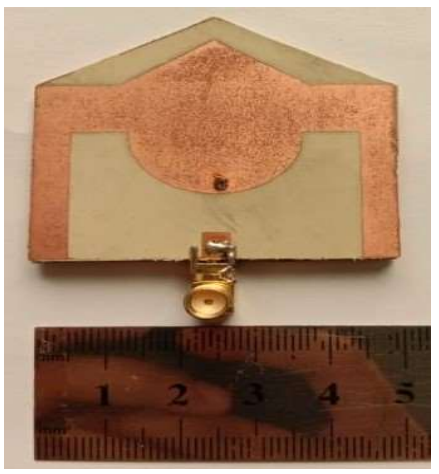

(a)

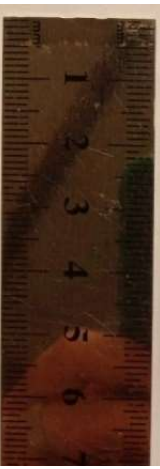

(b)

Gambar 10. Fabrikasi Antena Mikrostrip Kedua Tampak (a) Depan dan (b) Belakang 


\subsection{S-Parameter}

S-parameter pada hasil simulasi yang ditunjukkan oleh Gambar 11 berikut ini menunjukkan frekuensi kerja, return loss dan lebar bandwidth untuk antena yang diusulkan. Parameter return loss ini menunjukkan seberapa besar daya yang kembali atau dipantulkan ke antena. Jika daya yang kembali ke antena bernilai besar dari -10 dB maka akan mengurangi efisiensi dari kinerja antena dan dapat merusak transmitter yang terhubung langsung dengan antena.

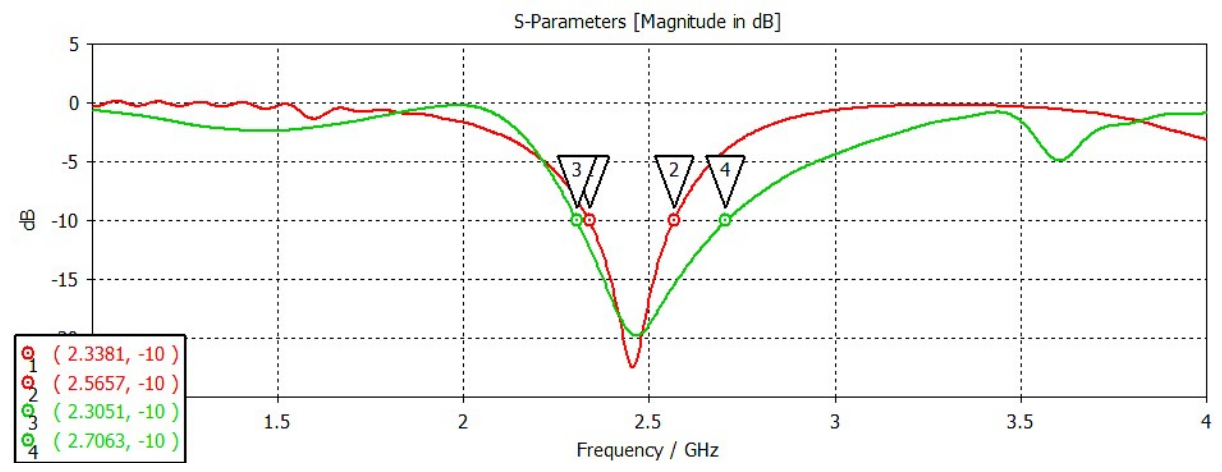

Gambar 11. Hasil Simulasi $S_{11}$ Antena yang Diusulkan

Berdasarkan Gambar 11 diatas memperlihatkan S-Parameter kedua antena mikrostrip yang diusulkan. S-Parameter antena pertama ditunjukkan oleh grafik berwarna hijau yang memperlihatkan frekuensi kerja 2,46 GHz dengan return loss $-19,76 \mathrm{~dB}$ dan bandwidth selebar 401,2 MHz. Sementara S-Parameter antena kedua ditunjukkan oleh grafik berwarna merah yang memperlihatkan frekuensi kerja $2,45 \mathrm{GHz}$ dengan return loss $-22,51 \mathrm{~dB}$ dan bandwidth selebar 227,6 $\mathrm{MHz}$.

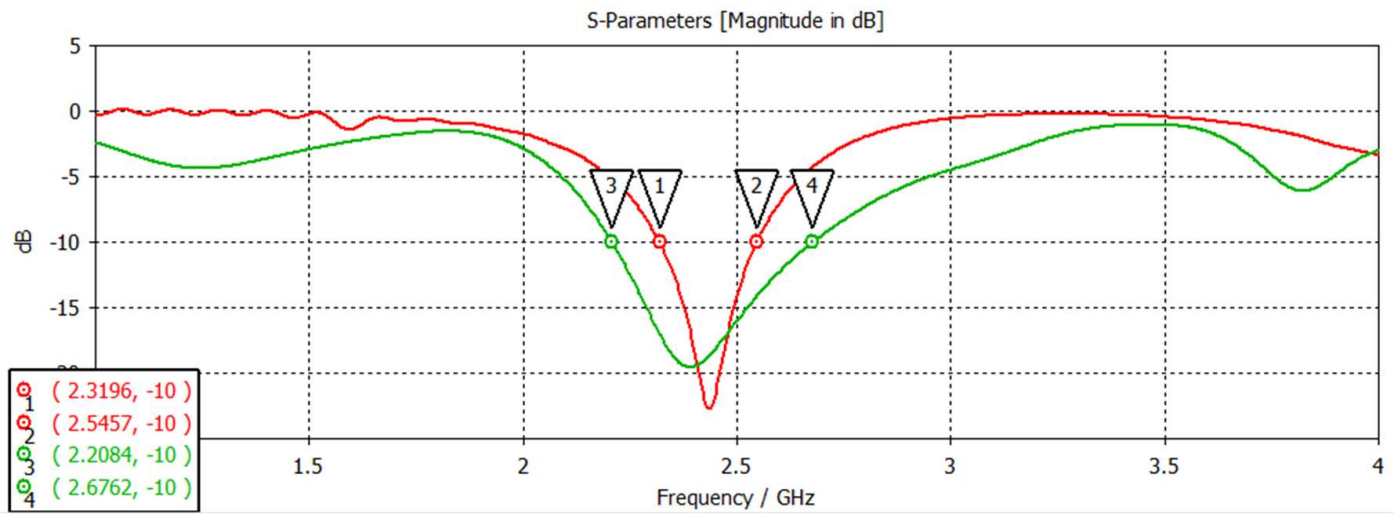

Gambar 12. Hasil Simulasi $S_{11}$ Pengujian Antena dengan Phantom Darah

Berdasarkan Gambar 12 diatas memperlihatkan S-Parameter kedua antena mikrostrip yang diusulkan yang disimulasikan dengan penambahan phantom darah. S-Parameter antena pertama ditunjukkan oleh grafik berwarna hijau yang memperlihatkan frekuensi kerja mengalami penurunan menjadi 2,38 GHz dengan return loss $-18,67 \mathrm{~dB}$ dan bandwidth selebar 467,8 MHz. Sementara S-Parameter antena kedua ditunjukkan oleh grafik berwarna merah yang memperlihatkan frekuensi kerja mengalami penurunan menjadi 2,43 $\mathrm{GHz}$ dengan return loss -22,73 dB dan bandwidth selebar 166,1 MHz. 


\subsection{Impedansi}

Impedansi masukan antena merupakan perbandingan antara tegangan dan arus, dimana antena berasal dari feedline. Antena pemancar yang akan dihubungkan ke antena pada umumnya menggunakan saluran transmisi dengan impedansi sebesar $50 \mathrm{ohm}$. Nilai impedansi antena yang diusulkan pada hasil simulasi ditunjukkan pada Gambar 13 berikut :

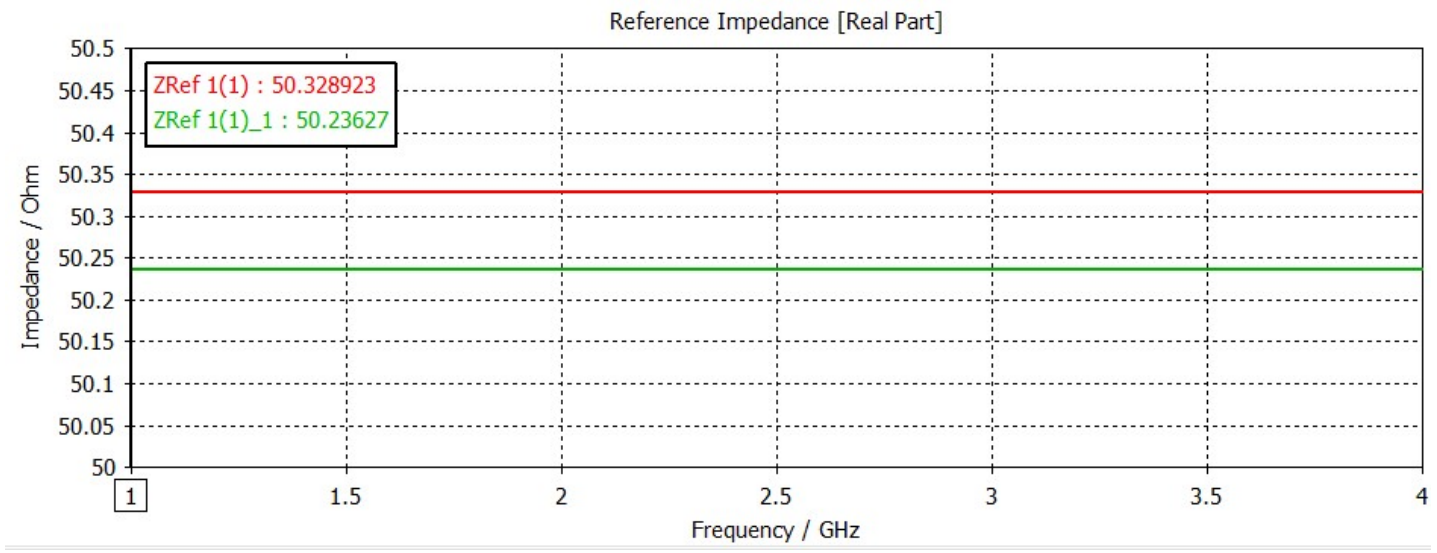

Gambar 13. Impedansi Masukan Antena yang Diusulkan

Berdasarkan Gambar 13 diatas memperlihatkan nilai impedansi antena pertama ditunjukkan oleh garis berwarna hijau dengan nilai 50,23 Ohm. Sementara nilai impedansi antena kedua ditunjukkan oleh garis berwarna merah dengan nilai impedansi 50,32 Ohm. Kedua impedansi yang dihasilkan mendekati impedansi saluran $50 \mathrm{ohm}$.

\subsection{Gain, Directivity dan Pola Radiasi}

Parameter gain, directivity dan pola radiasi memiliki pengaruh penting untuk memancarkan radiasi ke tubuh manusia. Parameter gain diharapkan menghasilkan cukup besar dan pola radiasi yang diperoleh diharapkan memiliki bentuk yang sempit dengan tujuan gelombang elektromagnetik yang dipancarkan terarah (Amaelia \& Hugeng., 2013). Hasil simulasi kedua antena pada CST Software dengan frekuensi kerja 2,4-2,5 GHz menghasilkan gain antena pertama sebesar 2,52 dBm, sementara antena kedua sebesar 3,44 dBm. Pola radiasi kedua antena berupa bidirectional. Hasil simulasi ditunjukkan pada Gambar 14 berikut :

Farfield Gain Abs (Phi=90)

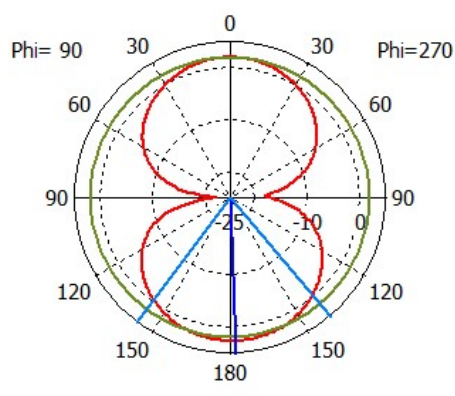

Theta / Degree vs. dBi

(a)

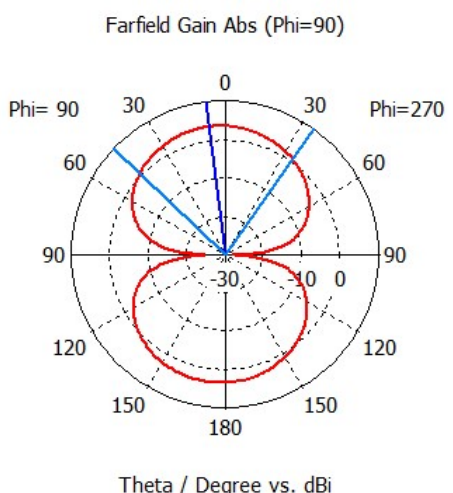

(b)

Gambar 14. Pola Radiasi (a) Antena Pertama dan (b) Antena Kedua 


\subsection{Arus}

Arus pada antena menunjukkan kinerja pergerakan kuat arus selama antena beroperasi. Simulasi pada CST Software menunjukkan kuat arus pergerakan antena ditandai dengan urutan tingkatan warna mulai dari biru, hijau, kuning dan merah. Berdasarkan Hasil simulasi arus pada Gambar 15 (a) antena pertama memperlihatkan kuat arus pada antena pertama bekerja dengan rentang $60,7 \mathrm{~mA} / \mathrm{m}$ hingga $101 \mathrm{~mA} / \mathrm{m}$. Sementara hasil simulasi arus pada Gambar 15 (b) antena kedua memperlihatkan kuat arus bekerja dengan rentang $62,7 \mathrm{~mA} / \mathrm{m}$ hingga $103 \mathrm{~mA} / \mathrm{m}$. Diperlihatkan pula dari kedua antena yang diusulkan bahwa arus masuk yang paling kuat berada di sepanjang feedline. Tampilan hasil simulasi arus pada kedua antena yang diusulkan ditunjukkan ada Gambar 15 berikut ini :
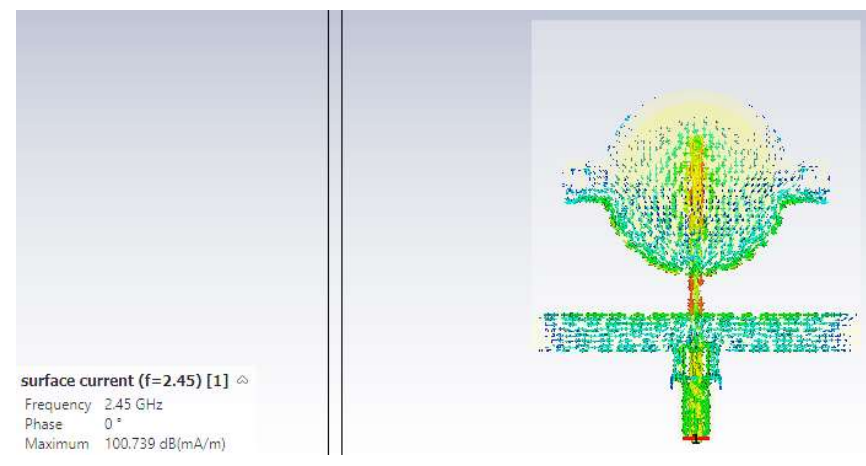

(a)
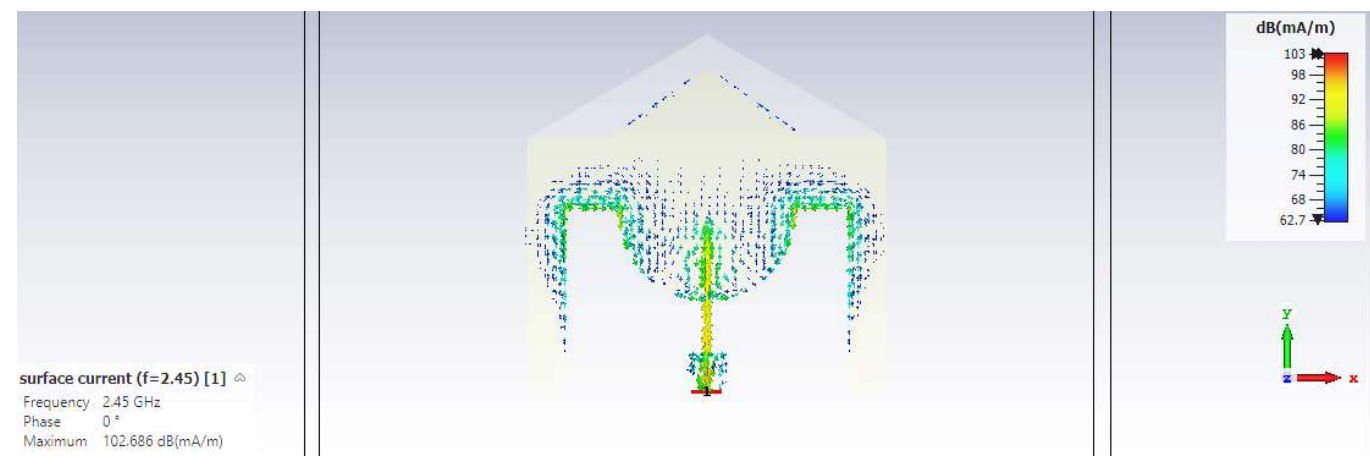

(b)

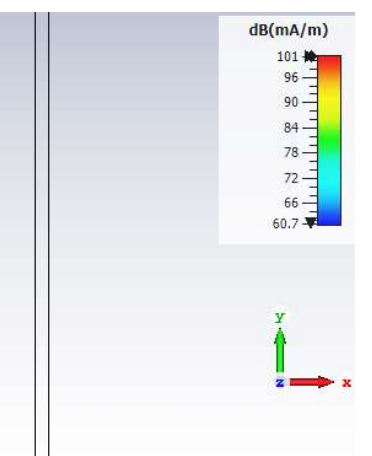

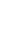

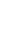


Tabel 3. Perbandingan Karakteristik dan Sensitivitas Antena Usulan

\begin{tabular}{|c|l|c|c|}
\hline \multirow{2}{*}{ No. } & \multicolumn{2}{|c|}{ Parameter } & \multicolumn{2}{c|}{ Jenis Antena } \\
\cline { 3 - 4 } & & Antena Pertama & Antena Kedua \\
\hline 1. & Frekuensi Kerja $(\mathrm{GHz})$ & 2,46 & 2,45 \\
\hline 2. & Return loss $(\mathrm{dB})$ & $-19,76$ & $-22,51$ \\
\hline 3. & Bandwidth $(\mathrm{MHz})$ & 401,2 & 227,6 \\
\hline 4. & Impedansi $(\Omega)$ & 50,23 & 50,32 \\
\hline 5. & VSWR & 1,22 & 1,16 \\
\hline 6. & Gain $(\mathrm{dBm})$ & 2,52 & 3,44 \\
\hline
\end{tabular}

\subsubsection{Perbandingan Hasil Simulasi Pengujian Antena Menggunakan Phantom Darah}

Tabel 4 berikut ini memperlihatkan adanya perbedaan hasil simulasi pengujian antena dengan phantom darah antara antena pertama dengan antena kedua. Hasil simulasi menunjukkan kedua antena usulan mengalami pergeseran frekuensi semakin menurun dengan adanya phantom darah. Apabila dibandingkan dengan hasil simulasi antena, pada antena pertama hasil simulasi juga memberi pengaruh terhadap penurunan return loss serta gain, namun bandwidth serta VSWR simulasi pengujian dengan phantom darah yang dihasilkan semakin lebar. Kemudian hasil pengujian antena kedua menunjukkan penurunan bandwidth, VSWR serta gain antena, sementara return loss pada antena semakin meningkat. Perbandingan hasil simulasi pengujian antena usulan menggunakan phantom darah yang ditunjukkan pada Tabel 4 berikut ini :

Tabel 4. Perbandingan Hasil Simulasi Pengujian Antena Usulan Menggunakan Phantom Darah

\begin{tabular}{|c|l|c|c|}
\hline \multirow{2}{*}{ No. } & \multicolumn{2}{|c|}{ Parameter } & \multicolumn{2}{c|}{ Jenis Antena } \\
\cline { 3 - 4 } & & Antena Pertama & Antena Kedua \\
\hline 1. & Frekuensi Kerja $(\mathrm{GHz})$ & 2,38 & 2,43 \\
\hline 2. & Return loss $(\mathrm{dB})$ & $-19,53$ & $-22,73$ \\
\hline 3. & Bandwidth $(\mathrm{MHz})$ & 467,8 & 226,1 \\
\hline 4. & Impedansi $(\Omega)$ & 50,23 & 50,35 \\
\hline 5. & VSWR & 1,23 & 1,15 \\
\hline 6. & Gain $(\mathrm{dBm})$ & 2,30 & 3,38 \\
\hline
\end{tabular}

\subsubsection{Perbandingan Hasil Simulasi dan Hasil Pengukuran}

Pada Gambar 16 berikut ini memperlihatkan grafik perbandingan antara hasil simulasi menggunakan CST Software dan hasil pengukuran yang dilakukan dengan menggunakan VNA. Gambar (a) antena pertama memperlihatkan hasil pengukuran menunjukkan terjadinya pergeseran frekuensi semakin meningkat yakni menjadi 2,5 GHz diikuti pergeseran return loss yang semakin rendah yaitu $-21,55 \mathrm{~dB}$ dibandingkan hasil pada saat simulasi yang diperoleh berupa frekuensi beroperasi pada 2,46 GHz dengan return loss -19,76 dB. Kemudian pada Gambar (b) memperlihatkan antena kedua yang diusulkan juga menunjukkan pergeseran frekuensi semakin meningkat yakni menjadi 2,47 GHz diikuti dengan pergeseran return loss yang semakin rendah yakni $-28 \mathrm{~dB}$ dibandingkan dengan hasil pada saat simulasi yang diperoleh frekuensi beroperasi pada $2,45 \mathrm{GHz}$ dengan return loss 22,51. Berikut ini merupakan gambar perbandingan antara hasil pengukuran dan hasil simulasi dari kedua antena yang diusulkan dapat dilihat pada Gambar 16 berikut : 
2D Graph 1

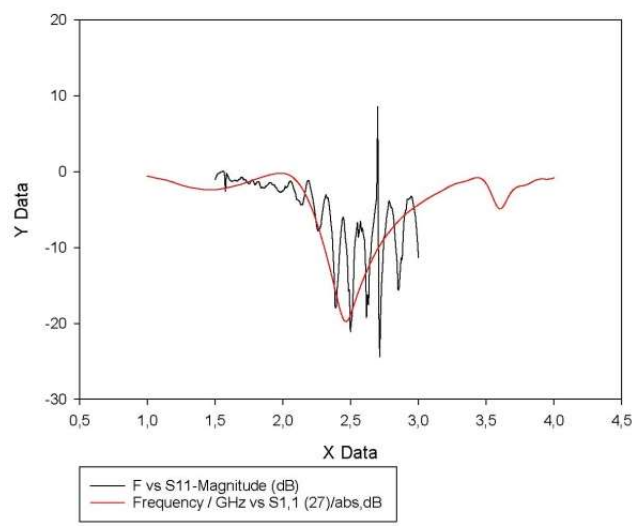

(a)

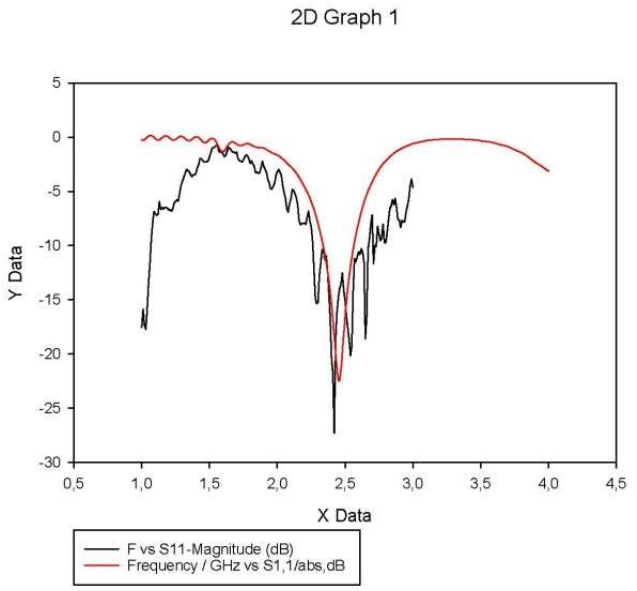

(b)

Gambar 16. Hasil Perbandingan (a) Antena Pertama dan (b) Antena Kedua

\section{KESIMPULAN}

Pada penelitian ini diusulkan dua model antena mikrostrip biosensor yang diaplikasikan untuk mendeteksi virus pada darah manusia. Antena yang diusulkan akan beroperasi pada frekuensi kerja 2,45 GHz $(2,4-2,45 \mathrm{GHz})$ dengan menggunakan teknik pencatu proximity coupled feed. Antena ini menggunakan material substrat Roger 3010 dengan ketebalan 1,28 $\mathrm{mm}$. Patch dan ground berada disepanjang permukaan substrat pertama. Hasil simulasi antena pertama menggunakan phantom darah menunjukkan pergeseran kinerja frekuensi dari 2,46 GHz menjadi 2,38 GHz. Pergeseran frekuensi kerja juga berlaku pada hasil simulasi antena kedua menggunakan phantom darah dari 2,45 GHz menjadi 2,43 GHz. Dengan demikian, simulasi pengujian antena menggunakan phantom darah memberikan dampak pergeseran frekuensi semakin rendah. Perbandingan hasil simulasi antena pertama dan kedua menunjukkan bahwa kinerja frekuensi antena kedua lebih optimal yakni 2,45 Ghz dibandingkan kinerja frekuensi antena pertama yakni 2,46 GHz. Sementara bandwidth antena pertama 401,2 MHz lebih baik dibandingkan antena kedua yakni 227,6 MHz. Return loss antena kedua $-22,51 \mathrm{~dB}$ lebih baik dibandingkan antena pertama yang hanya $-19,76 \mathrm{~dB}$. Impedansi antena pertama lebih optimal yakni 50,23 ohm sementara impedansi antena kedua 50,32 ohm. Berdasarkan simulasi arus yang bergerak pada antena, pergerakan arus antena pertama lebih kuat dibandingkan arus pada antena kedua. Hasil pengujian fabrikasi antena pertama beroperasi pada frekuensi 2,5 GHz sementara antena kedua beroperasi 2,47 GHz. Return loss hasil pengujian antena kedua lebih optimal yakni -28 dB dibandingkan antena pertama hanya $-21,55 \mathrm{~dB}$. Sehingga, dapat ditarik kesimpulan bahwa hasil pengujian fabrikasi kedua antena mengalami pergeseran frekuensi kerja yang semakin meningkat serta return loss yang semakin rendah dibandingkan dengan hasil pada saat simulasi. Meskipun demikian, hasil pengujian kedua antena telah memenuhi karakteristik antena yang diharapkan. 


\section{UCAPAN TERIMA KASIH}

Penelitian ini merupakan penelitian dasar (kompetitif nasional) yang didanai oleh Direktorat Riset dan Pengabdian kepada Masyarakat (DRPM) Ristek-BRIN tahun 2021. Penulis mengucapkan terima kasih kepada Lab Dasar Teknik Elektro dan Lab Mikrobiologi Fakultas Kedokteran, Universitas Riau atas fasilitas dan sarana yang diberikan. Tak lupa juga penulis mengucapkan terima kasih kepada LPPM Unri yang selalu mewadahi dan mensupport penelitian yang dilakukan. Penulis juga mengucapkan terima kasih kepada teman teman dari LIPI, Universiti Teknologi Malaysia yang selalu mendukung dan membantu segala kegiatan pengujian antena dan tambahan sarana yang diperlukan.

\section{DAFTAR RUJUKAN}

Abidah, A., Hidaayatullaah, H. N., Simamora, R. M., Fehabutar, D., \& Mutakinati, L. (2020). The Impact of Covid-19 to Indonesian Education and Its Relation to the Philosophy of "Merdeka Belajar." Studies in Philosophy of Science and Education, 1(1), 38-49. https://doi.org/10.46627/sipose.v1i1.9

Amaelia, F. Y., \& Hugeng. (2013). Sistem Antena Array Paralel untuk Menghasilkan Lobe Radiasi Utama dalam Arah Bervariasi. Tes/a, 15(2), 165-184.

Balanis, C. A. (2012). Antenna Theroy: Analysis and Design.

Cabigas, R. B. (2020). Covid 19: Impetus for Communty Spirits among Filipinos. Indonesian Journal of Science \& Technology, 2, 201-208. https://doi.org/https://doi.org/10.17509/ijost.v5i2.24479

Cheng, D., He, X., Huang, X., Zhang, B., Liu, G., Shu, G., Fang, C., Wang, J., \& Luo, Y. (2018). Terahertz biosensing metamaterial absorber for virus detection based on spoof surface plasmon polaritons. International Journal of $R F$ and Microwave Computer-Aided Engineering, 28(7), 1-7. https://doi.org/10.1002/mmce.21448

Development Bank, A. (2020). The Economic Impact of the COVID-19 Outbreak on Developing Asia. 9(128). https://doi.org/10.22617/BRF200096

Dolai, S., \& Tabib-azar, M. (2020). Terahertz Detection of Zika Viruses. Preprints, February. https://doi.org/10.20944/preprints202002.0232.v1

Elsheakh, D., Elsadek, H., Abdullah, E., Atteya, S., \& Elmazny, W. N. (2013). Novel rapid detection of different viruses in blood using microimmuno-sensor. 2013 7th European Conference on Antennas and Propagation, EuCAP 2013, (pp. 1128-1131).

Elsheikh, D. M., Elsadek, H. A., Abdallah, E. A., Atteya, S., \& Elmazny, W. N. (2013). Rapid detection of blood entero-viruses using microstrip antenna bio-sensor. European Microwave Week 2013, EuMW 2013 - Conference Proceedings; EuMC 2013: 43rd European Microwave Conference, (pp. 878-880). 
HARIYANI, Y. S., HADIYOSO, S., \& SIADARI, T. S. (2020). Deteksi Penyakit Covid-19 Berdasarkan Citra X-Ray Menggunakan Deep Residual Network. ELKOMIKA: Jurnal Teknik Energi Elektrik, Teknik Telekomunikasi, \& Teknik Elektronika, \&(2), 443. https://doi.org/10.26760/elkomika.v8i2.443

Keshavarz, A., \& Vafapour, Z. (2019). Sensing avian influenza viruses using terahertz metamaterial reflector. IEEE Sensors Journal, 19(13), 5161-5166. https://doi.org/10.1109/JSEN.2019.2903731

Kiourti, A., \& Nikita, K. S. (2012). Miniature scalp-implantable antennas for telemetry in the MICS and ISM bands: Design, safety considerations and link budget analysis. IEEE Transactions on Antennas and Propagation, 60(8), 3568-3575. https://doi.org/10.1109/TAP.2012.2201078

Luo, G., \& Gao, S. J. (2020). Global health concerns stirred by emerging viral infections. Journal of Medical Virology, 92(4), 399-400. https://doi.org/10.1002/jmv.25683

Park, S. J., Cha, S. H., Shin, G. A., \& Ahn, Y. H. (2017). Sensing viruses using terahert nano-gap metamaterials. Biomedical Optics Express, $8(8), 3551$. https://doi.org/10.1364/boe.8.003551

Pawar, M. (2020). The Global Impact of and Responses to the COVID-19 Pandemic. The International Journal of Community and Social Development, 2(2), 111-120. https://doi.org/10.1177/2516602620938542

Tong, K. F., \& Huang, J. (2008). New proximity coupled feeding method for reconfigurable circularly polarized microstrip ring antennas. IEEE Transactions on Antennas and Propagation, 56(7), 1860-1866. https://doi.org/10.1109/TAP.2008.924736

Zang, F., Su, Z., Zhou, L., Konduru, K., Kaplan, G., \& Chou, S. Y. (2019). Ultrasensitive Ebola Virus Antigen Sensing via 3D Nanoantenna Arrays. Advanced Materials, 31(30), 1-9. https://doi.org/10.1002/adma.201902331 